\title{
Effect of ethanol extract of Syzygium cumini (L.) pulp on blood pressure and malondyaldehyde level of chronic restraint stress rats
}

\author{
Mega Febia Suryajayanti ${ }^{1}$, Anggi Laksmita Dewi ${ }^{1}$, Bira Arumndari Nurrahma ${ }^{1}$, Ayu Dewi \\ Silvia Putri ${ }^{2}$, Zunamilla Khairia ${ }^{1}$, Arta Farmawati ${ }^{3}$ \\ ${ }^{1}$ School of Nutrition \& Health, ${ }^{2}$ School of Nursing, ${ }^{3}$ Department of Biochemistry, Faculty \\ of Medicine, Universitas Gadjah Mada, Yogyakarta, Indonesia
}

DOI: http://dx.doi.org/10.19106/JMedSci004903201703

\begin{abstract}
Chronic stress disturbs the equilibrium of oxidant-antioxidant redox in the human body which accelerates cellular aging lead to promotes earlier onset of age-related diseases. To against the chronic stress human body needs exogenous antioxidant. Syzygium cumini (L.) has high antioxidant activity due to it's high anthocyanin content. Therefore, this plant is potential to develop as a natural antioxidant. The aim of the study was to investigate the effect of ethanol extract of $S$. cumini (L.) pulp on blood pressure and malondialdehyde (MDA) level of rats induced by restraint stress. Twenty male Wistar rats were used in this study which divided into 4 groups with 5 rats in each group i.e. normal control, negative control and 2 treatment groups which given ethanol extract of S. cumini (L.) pulp at doses of 100 and $200 \mathrm{mg} / \mathrm{g}$ body weight (BW), respectively. Restraint stress was carried out by placing the rats in restraint rat for 30 minutes daily for 7 days. Blood pressure was measured before and after the treatment while MDA level was measured after the treatment. One-Way ANOVA was used to analyze the data. The results showed that induction of the restraint stress significantly increased blood pressure of the rats $(p<0.001)$. The administration of ethanol extract of $S$. cumini (L.) pulp significantly prevented the increase in blood pressure of chronic restraint stress rats $(p<0.001)$. Furthermore, the MDA level of the treatment groups was significantly lower than that of negative control $(p<0.05)$ indicating that ethanol extract of $S$. cumini (L.) pulp could prevent the increase in the MDA level. In conclusion, administration of ethanol extract of $S$. cumini (L.) pulp can prevent the increase in blood pressure and MDA level of chronic restraint stress rats.
\end{abstract}

\section{ABSTRAK}

Stres kronik mengganggu keseimbangan senyawa oksidan-antioksidan yang memicu penuaan selular dan menyebabkan timbulnya penyakit yang berkaitan dengan penuaan lebih awal. Untuk melawan stress kronis tubuh memerlukan antioksidan oksidan. Syzygium cumini (L.) mempunyai aktivitas antioksidan yag tinggi karena kandungan antsianinya. Oleh Karena itu, tanaman ini potensial untuk dikembangkan sebagai antioksidan alami. Tujuan penelitian ini adalah mengkaji efek ekstrak etanol bubur S. cumini (L) terhadap tekanan darah dan kadar malondialdehid (MDA) tikus yang diinduksi stres dengan dikekang. Duapuluh tikus jantan Wistar digunakan dalam penelitian ini dibagi menjadi 4 kelompok

Corresponding author: mega.febia.s@mail.ugm.ac.id 
masing-masing terdiri 5 ekor tikus yaitu kontrol normal, kontrol negatif dan 2 kelompok perlakuan yang diberi ekstrak etanal bubur S. cumini (L) dosis berturut-turut 100 dan 200 $\mathrm{mg} / \mathrm{g}$ berat badan (BB). Tikus dibuat stres dengan menempatkan tikus dalam pengekang selama 30 menit setiap hari selama 7 hari. Tekanan darah diukur sebelum dan sesudah perlakuan, sedangkan kadar MDA diukur setelah perlakuan. Data yang diperoleh dianalisis dengan ANOVA satu jalan. Hasil penelitian menunjukkan induksi stres dengan pengekang secara nyata meningkatkan tekanan darah tikus $(p<0.001)$. Pemberian ekstrak bubur etanol S. cumini (L) secara nyata mencegah kenaikan tekanan darah tikus stres akibat dikekang secara kronis $(p<0.001)$. Selanjutnya kadar MDA kelompok perlakuan lebih rendah secara nyata dibandingkan kontrol negatif $(p<0.05)$ yang menunjukkan bahwa ekstrak etanol bubur S. cumini (L) dapat mencegah kenaikan kadar MDA. Dapat disimpulkan bahwa pemberian ekstrak etanol bubur S. cumini (L) dapat mencegah kenaikan tekanan darah dan kadar MDA tikus stres kronis akibat dikekang.

Keywords: Syzygium cumini (L) - restraint stress - malondialdehyde - blood pressure antioxidant

\section{INTRODUCTION}

In globalization era, people work very hard and strenuous due to the pressure from world development, school and universities tasks, family problems, bullying, all negative perception and others. An unbalanced position between everything that people's want and their ability to reach it was reported. This causes the incidence of stress around the world is increasing more and more. This condition affects the brain, hormone and neurotransmitter activities which worsen people's health and lower their productivity. ${ }^{1,2}$

Chronic stress condition increases free radicals in the body resulting in lipid peroxides. Continuous lipid peroxide reaction can destroy cell, tissue and organ which is related to it. If the antioxidant in the body can't work normally, there will be unbalanced condition of oxidant in the body and the antioxidant. This condition can lead to faster cell aging so the incident of age-related disease such as cardiovascular disease, degenerative disease and cancer can come even though people be still young. ${ }^{3,4}$ Antioxidants are needed by the body to prevent reactions due to high free radical in the body. Generally, the reaction is destructive so it can harm the body. The high antioxidant content also has a huge potential in managing oxidative stress. The decrease of oxidative stress will reduce the risk of chronic diseases such as cancer, diabetes, and stroke. ${ }^{5}$

One of the parameters that can be used to determine the condition of stress is malondialdehyde (MDA) level. MDA is the result of lipid peroxidation reaction. It can be made as one of the parameters of stress because it is known to mark the presence of free radicals in the body due to oxidative stress. ${ }^{6}$ In addition, other parameter that can be used is the blood pressure. Basically, when there's an increasing oxidative stress in the body, there will be also an increase in renal vasoconstriction resulting in increased blood pressure. $^{7}$

Indonesia is a country that has a big diversity of tropical fruits. One type of tropical fruit which is full of benefits is S. cumini (L), locally name is jamblang. Syzygium cumini (L) fruit is a traditional fruit that has been used by people to treat various diseases, such as gastrointestinal disease, hypertension, and diabetes. ${ }^{8}$ Recently, this fruit is known to have a fairly high antioxidant content. Inside, there is a natural anthocyanin which plays 
an important role in the main antioxidant for antioxidant activity in $S$. cumini (L) fruit. Other antioxidants such as vitamin $\mathrm{C}$, as well as the diverse group of polyphenols, such as tannins are also been there. ${ }^{9-11}$ This study aimed to evaluate the effect of S. cumini (L) fruit extract in stress parameters in rats with chronic conditions using restraint stress.

\section{MATERIALS AND METHODS}

\section{Experimental animals}

Twenty male Wistar rats aged 2 months with a body weight of 150-200 g were obtained from the Center for Food and Nutrition Studies Universitas Gadjah Mada, Yogyakarta, Indonesia. Rats which were sick or anorexia during acclimatization, had disordered, and died during experiment were excluded from this study. Rats were acclimatized for 3 days. Rats were housed in a solid plastic cage with standard light (12 h) and dark (12 h) cycles were maintained throughout the experimental period. Rats were fed with AD diet and water ad libitum. Protocol of this study has been approved by the Medical and Health Research Ethics Committee, Faculty of Medicine, Universitas Gadjah Mada, Yogyakarta.

\section{Preparation of $S$. cumini (L) extract}

Ripe S. cumini (L) fruits were purchased from the local market in Yogyakarta Special Region. After removal of seeds of the fruits, the pulps were aired until the water content in S. cumini (L) pulps slightly reduced. Pulps drying process was continued by oven at $40^{\circ} \mathrm{C}$ for 6 days, then crushed and sifted ( 8 mesh). In the room temperature, $S$. cumini (L) flour were extracted by maceration with ethanol $70 \%$ (ratio flour and solvent is 1:2) for 24 hours. Solvent were evaporated with rotary evaporator at $40^{\circ} \mathrm{C} .^{12,13}$ The extraction was conducted at the Laboratory of Pharmacology,
Department of Pharmacology and Therapy, Faculty of Medicine Universitas Gadjah Mada.

\section{Experimental procedure}

On the first day of experimental, body weight and blood pressure of the rats were measured. The rats were divided into 4 groups with 5 rats in each group i.e. normal control, negative control and 2 treatment groups which given ethanol extract of $S$. cumini (L.) pulp at doses of 100 and $200 \mathrm{mg} / \mathrm{g}$ body weight $(\mathrm{BW})$, respectively. The extracts were given daily at $08.00 \mathrm{AM}$ for 7 days, while restraint stress was carried out immediately after treatment with the extracts by placing the rats in restraint rat made from PVC for 30 minutes daily for 7 days. ${ }^{14}$ Body weight and blood pressure was measured before and after the treatment. One $\mathrm{mL}$ of blood plasma of all groups after treatment was collected from medial canthus sinus orbitalis for MDA examination. The MDA level was measured spectrophotometrically at $535 \mathrm{~nm}$ by using thiobarbituric acid-reactive substances (TBARS) method. ${ }^{15}$

\section{Statistical analysis}

Data of blood pressure and MDA level were presented as mean \pm Standard of Deviation (SD). Differences between multiple groups were compared using Oneway analysis of variance and continued using Post Hoc Tukey HSD analysis. All statistical analysis were performed using SPSS program for Windows. A $p$ value $<0.05$ was considered to be statistical significant.

\section{RESULTS}

The increase of blood pressure of negative control before and after test was 20.8 times higher than that normal control (FIGURE 
1). It was indicated that the restraint stress significantly increased blood pressure of the rats $(\mathrm{p}<0.001)$. Moreover, the administration of ethanol extract of $S$. cumini (L.) pulp significantly prevented the increase in blood pressure of chronic restraint stress rats $(\mathrm{p}<0.001)$. The increase of blood pressure of treatment groups was significantly lower than that negative control $(\mathrm{p}<0.001)$. However, it was still significantly higher than that normal control i.e. 6 and 2.7 times higher at dose of 20 and $40 \mathrm{mg} / \mathrm{kg} \mathrm{BW}$, respectively (FIGURE $1)$.

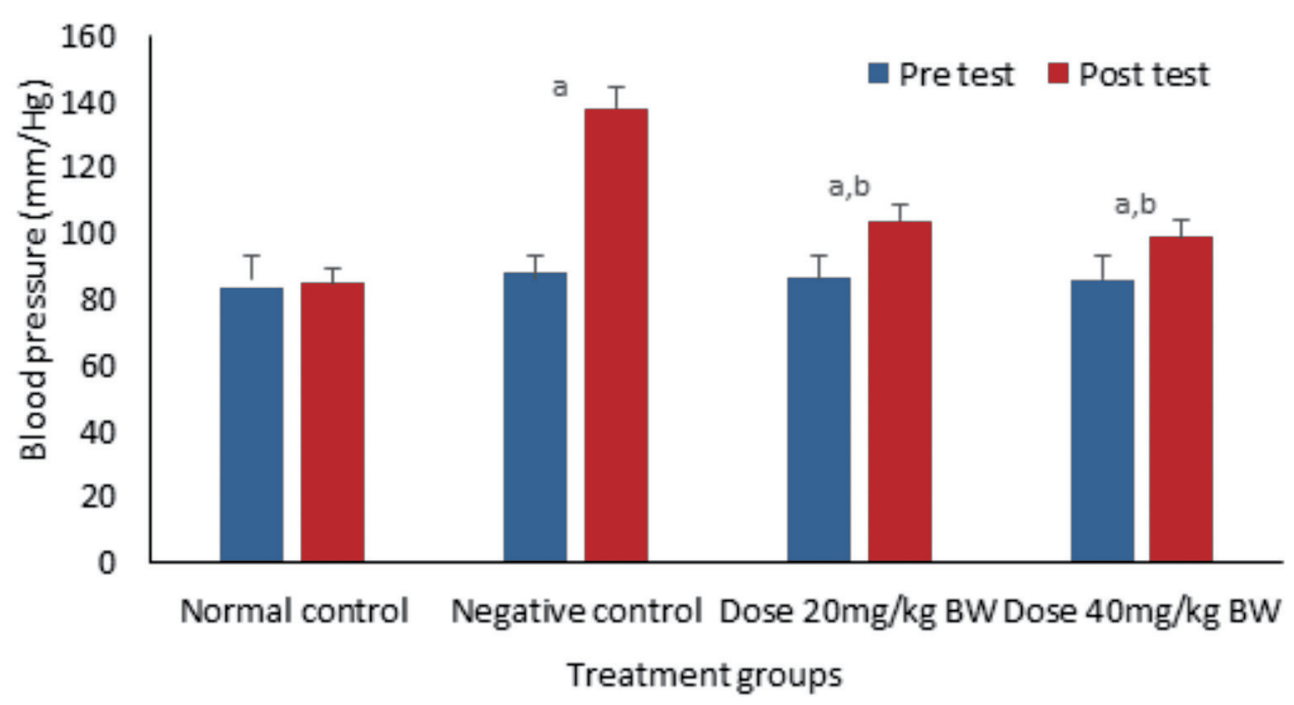

FIGURE 1. The blood pressure of all groups before and after the treatment ethanol extract of S. cumini (L) pulp. a) significantly different with normal control $(\mathrm{p}<0.001)$; b) significantly different with negative control $(\mathrm{p}<0.001)$.

The MDA level of rats after induction of the restraint stress (negative control) was significantly higher than that normal control and treatment groups as presented in FIGURE $2(p<0.001)$. It was indicated that the induction of the restraint stress could increase the MDA level of rats and administration of the ethanol extract of S. cumini (L) pulp could prevent the increase in the MDA level. However, the prevention by the ethanol extract of $S$. cumini (L) could not achieve at the MDA normal level. The MDA level after administration of the ethanol extract of $S$. cumini (L) pulp was still higher than that normal control i.e. 2.7 and 2 times higher at the dose of 20 and 40 $\mathrm{mg} / \mathrm{kg} \mathrm{BW}$, respectively (FIGURE 2). 


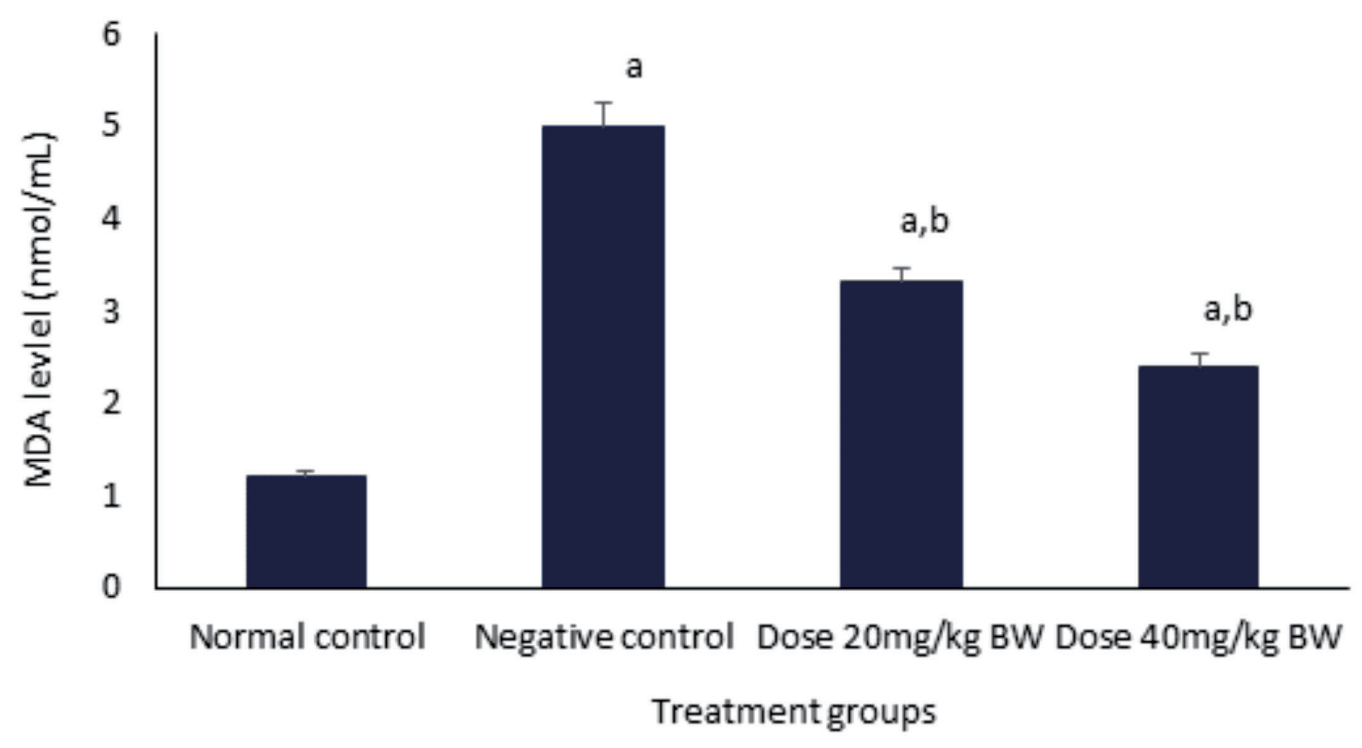

FIGURE 2. The MDA level after the treatment ethanol extract of S. cumini (L) pulp. a) significantly different with normal control $(\mathrm{p}<0.001)$; b) significantly different with negative control $(\mathrm{p}<0.001)$.

\section{DISCUSSION}

Syzygium cumini (L) was reported posses some biological activities such as cardioprotective, antioxidant, hypoglycemic, antidiabetic and antinociceptive effects. ${ }^{16} \mathrm{~A}$ phytochemical study showed that edible fruit extract of S. cumini (L) contains phenolic acids that promotes hypotensive and bradycardic effects in normotensive non-anaesthetized rats. ${ }^{17}$ The mechanisms of S. cumini (L) in the prevention of hypertension is probably through inhibition of the activity of $\mathrm{Ca}^{2+}$ in the endothelium deprived mesnteric arteries by the active constituents of contained in $S$. cumini $(\mathrm{L}) .{ }^{18} \mathrm{The}^{\mathrm{Ca}^{2+}}$ is known as the primary regulator of the vascular smooth muscle.

Another possibility of mechanisms of action is through inhibition of angiotensin converting enzyme (ACE) by anthocyanin in S. cumini (L) to decrease the production of angiotensin II from angiotensin I that result in vasodilatation and therefore decreased blood pressure. ${ }^{19}$ In addition, anthocyanin is reported possess antioxidant activity that increase nitric oxide synthase (NOS) resulting the vasodilatation of the bloodartery. ${ }^{17,19}$

The oxidative stress can increase the free radicals that induce the lipid peroxidation such as MDA. ${ }^{20}$ This hypothesis was supported by this study that demonstrated the restraint stress increased the MDA level of rats. Furthermore, administration of the ethanol extract of $S$. cumini (L) pulp could prevent the increase in the MDA level. The possibility mechanism of action of $S$. cumini (L) as antioxidant is through induction of glutation reductase in oxidative stress that result reduction of the lipid peroxidation and free radicals formation. ${ }^{21}$

\section{CONCLUSION}

In conclusion, administration of ethanol extract of S. cumini (L.) pulp can prevent the increase in blood pressure and MDA level of chronic restraint stress rats. Further study is 
needed to evaluate the mechanism of actions of $S$. cumini (L) as antioxidative stress.

\section{ACKNOWLEDGEMENTS}

This study was financially supported by Ministry of Research, Technology and High Education of the Republic of Indonesia through the Students' Creativity Program scheme 2016-2017.

\section{REFERENCES}

1. Conrad CD. A critical review of chronic stress effects on spatial learning and memory. Prog Neuropsychopharmacology Biol Psychiatry 2010; 34(5):742-55. http://dx.doi. org/10.1016/j.pnpbp.2009.11.003

2. Widiana LR. Hubungan Stress dengan Produktivitas Tenaga Kerja Wanita Bagian Linting Rokok di PT. Djitoe Indonesian Tobacco Surakarta [Dissertation]. Surakarta: Universitas Sebelas Maret; 2011.

3. Khansari N, Shakiba Y, Mahmoudi M. Chronic inflammation and oxidative stress as a major cause of age-related diseases and cancer. Recent Pat Inflamm Allergy Drug Discov 2009; 3(1):73-80. https://doi. org/10.2174/187221309787158371

4. Epel ES. Psychological and metabolic stress: a recipe for accelerated cellular aging. Hormones (Athens) 2009; 8(1):7-22. https:// doi.org/10.14310/horm.2002.1217

5. Zafir A, Banu N. Induction of oxidative stress by restraint stress and corticosterone treatments in rats. Indian J Biochem Biophys 2009; 46(1):53-8.

6. Fajrilah BR, Indrayani UD, Djam'an Q. Pengaruh pemberian madu terhadap kadar malondialdehyde (MDA) plasma darah pada tikus yang diinduksi alloxan: studi experimental pada tikus putih jantan galur Wistar. Sains Medika 2013; 5(2):98$100 . \quad$ https://doi.org/10.1111/j.1472- 8206.2009.00700.x

7. Reckelhoff JF. Gender differences in the regulation of blood pressure. Hypertension 2001; 37(5):1199-208. https://doi. org/10.1161/01.HYP.37.5.1199

8. Bopp A, De Bona KS, Bellé LP, Moresco RN, Moretto MB. Syzygium cumini inhibits adenosine deaminase activity and reduces glucose levels in hyperglycemic patients. Fundam Clin Pharmacol 2009; 23(4):5017. http://dx.doi.org/ 10.1111/j.14728206.2009.00700.x

9. Marliani L, Kusriani H, Sari NI. Aktivitas antioksidan daun dan buah jamblang (Syzygium cumini, L.) skeel. Prosiding SNaPP: Sains dan Teknologi. 2014; 4(1):2016.

10. Chaudhary B, Mukhopadhyay K. Syzygium cumini (L.) skeels: a potential source of nutraceuticals. Int J Pharm Biol Sci 2012; 2(1):46-53.

11. Zhang LL, Lin YM. Antioxidant tannins from Syzygium cumini fruit. Afr J Biotechnol 2009; 8(10):2301-9.

12. Lestario LN, Hastuti P, Raharjo S. Sifat antioksidatif ekstrak buah duwet (Syzygium cumini). Agritech 2005; 25(1): 24-31.

13. Sari P. Potensi antosianin buah duwet (Syzygium cumini) sebagai pewarna pangan alami yang memiliki kemampuan antioksidasi. [Dissertation]. Bogor: Program Pasca Sarjana Institut Pertanian Bogor; 2011.

14. Lucca G, Comim CM, Valvassori SS, Réus GZ, Vuolo F, Petronilho F, Dal-Pizzol F, et al. Effects of chronic mild stress on the oxidative parameters in the rat brain. Neurochem Int 2009; 54(5-6):358-62. http://dx.doi. org/10.1016/j.neuint.2009.01.001

15. Bird RP, Draper AH. Comparative studies on different methods of malondyhaldehyde determination. Methods Enzymol 1984; 90:105-110 
16. Ayyanar M, Subash-Babu P. Syzygium cumini (L.) Skeels: a review of its phytochemical constituents and traditional uses. Asian Pac J Trop Biomed 2012; 2(3):240-6. http://dx.doi. org/10.1016/S2221-1691(12)60050-1

17. Herculano ED, da Costa C, Rodriques AK, Araújo-Júnior JX, Santana EG, França PH, et al. Evaluation of cardiovascular effects of edible fruits of Syzygium cumini Myrtaceae (L) skeels in rats. Trop J Pharm Res 2014; 13(11):1853-61. https://doi.org/10.4314/ tjpr. v13i11.12

18. Ribeiro RM, Pinheiro Neto VF, Ribeiro KS, Vieira DA, Abreu IC, Silva Sdo N, et al. Antihypertensive effect of Syzygium cumini in spontaneously hypertensive rats. Evid Based Complement Alternat Med 2014;
2014:605452. http://dx.doi.org/10.1155/ 2014/605452

19. Kusumastuti IR. Roselle (Hibiscus sabdariffa Linn) effects on lowering blood pressure as a treatment for hypertension. J Majority 2014; 3(7):70-4.

20. Siswonoto S. Hubungan kadar malondialdehid plasma dengan keluaran klinis stroke iskemik akut. [Dissertation]. Semarang: Program Pasca Sarjana Universitas Diponegoro; 2008.

21. Ologundudu A, Ologundudu AO, Oluba OM, Omotuyi IO, Obi FO. Effect of Hibiscus sabdariffa anthocyanins on 2, 4-dinitrophenylhydrazine-induced tissue damage in rabbits. J Toxicol Environ Health Sci 2010; 2(1):1-6. 